\title{
When do skills become obsolete, and when does it matter?
}

Citation for published version (APA):

Allen, J. P., \& van der Velden, R. K. W. (2002). When do skills become obsolete, and when does it matter? In A. D. Grip, J. V. Loo, \& K. Mayhew (Eds.), The economics of skills obsolescence: theoretical innovations and empirical applications (pp. 27-50). Elsevier Science. Research in Labor Economics No. Vol. 21 https://doi.org/10.1016/s0147-9121(02)21004-3

Document status and date:

Published: 01/01/2002

DOI:

10.1016/s0147-9121(02)21004-3

Document Version:

Publisher's PDF, also known as Version of record

\section{Please check the document version of this publication:}

- A submitted manuscript is the version of the article upon submission and before peer-review. There can be important differences between the submitted version and the official published version of record.

People interested in the research are advised to contact the author for the final version of the publication, or visit the DOI to the publisher's website.

- The final author version and the galley proof are versions of the publication after peer review.

- The final published version features the final layout of the paper including the volume, issue and page numbers.

Link to publication

\footnotetext{
General rights rights.

- You may freely distribute the URL identifying the publication in the public portal. please follow below link for the End User Agreement:

www.umlib.nl/taverne-license

Take down policy

If you believe that this document breaches copyright please contact us at:

repository@maastrichtuniversity.nl

providing details and we will investigate your claim.
}

Copyright and moral rights for the publications made accessible in the public portal are retained by the authors and/or other copyright owners and it is a condition of accessing publications that users recognise and abide by the legal requirements associated with these

- Users may download and print one copy of any publication from the public portal for the purpose of private study or research.

- You may not further distribute the material or use it for any profit-making activity or commercial gain

If the publication is distributed under the terms of Article $25 \mathrm{fa}$ of the Dutch Copyright Act, indicated by the "Taverne" license above, 


\section{WHEN DO SKILLS BECOME OBSOLETE, AND WHEN DOES IT MATTER?}

\section{Jim Allen and Rolf van der Velden}

\section{ABSTRACT}

In our analyses, using data on Dutch tertiary education graduates, we use a direct measure for skills obsolescence based on workers" self-assessment. On average, almost a third of the skills obtained in tertiary education were obsolete seven years later. Skills obsolescence is strongly related to rapid changes in work domain, and to shortcomings in tertiary education. Obsolescence occurs as much in generic as in specific fields of study. It is only weakly related to current skill shortages, and not at all to the prospects for further skill acquisition, wages and investments in additional training.

\section{INTRODUCTION}

One of the most prominent issues on the public policy agenda over the last two decades has been the importance of a well-trained workforce and the impact of technological and organizational developments on the skills needed in the economy. In 1990, the Industrial Research and Development Advisory Committee of the Commission of the European Communities (IRDAC) stated that "the information revolution ... is rendering much of the previous education

The Economics of Skills Obgolescence, Volume 21, pages 27-50.

Copyright 02002 by Lisevier Science Ltd.

All rights of reproduction in any form reserved.

ISBN: 0-7623-0960-1 
and training obsolete or simply irrelevant. It is salutary to note that even if useful knowledge has a half-life as long as ten years, intellectual capital is then depreciating at $7 \%$ year (which is a much higher rate than the recruitment of new graduates), with a corresponding reduction in the effectiveness of the workforce" (IRDAC, 1990, pp. II). Ten years later this statement has hardly lost any of its relevance. The European Commission continues to stress the need for investment in education and training to improve the competitiveness of Europe's economies. In the U.K., the government set up a National Skills Task Force to help create a National Skills Agenda. In their first report they remark: "We live in an age of globall competition and constant change. We must seek to achieve a high skill, high value added economy as the recipe for national competitiveness. For a truly dynamic economy, we must keep the skills of our people ahead of the curve" (National Skills Task Force, 1998, p. 5).

The public policy debate in this area coincides with a long radition of research on Skill Biased Technological Change. Most of this research has focused on the possible upgrading effects of technological and organizational changes, showing general increases in the required skill levels (Machin \& Van Reenen, 1998; Wolff, 2000). This gradually led to a change in perspective, from an overall concern for the effects of over education in the $1970 \mathrm{~s}$ and 1980 s to a growing concern for skills shortages in the 1990s. Much of the skill biased technological change is due to shifts in the sectoral and occupational structure, with an increase in demand for higher skilled positions and a decrease in demand for lower skilled labor" (Cörwers et al., 2002). Although these changes in the composition of the labor market clearly reflect a depreciation of the economic value of lower level skills, this form of skills obsolescence is different from the kind of obsolescence that originates from the actual ageing of knowledge and skills. The latter reflects what might be called "job specific skill obsolescence," which result from technological or organizational developments in the production process. It is this type of Job Specific Skill Obsolescence (hereafter referred to as JSSO) that we will focus on in this paper. In this paper, we explicitly restrict our definition of JSSO to the ageing of knowledge and skills that were originally acquired in education. It is important to note that ISSO is not the same as skills shortages. Skills shortages refer to a discrepancy between the actual skills someone possesses and the skillls required in a job. This discrepancy may be a result of JSSO, but it may also be caused by other factors, like having followed the "wrong" type of education. And the other way around, not all ISSO results in skills shortages. By following additional training, people can replenish their skills, thereby avoiding skills shortages. 
The popular view towards ISSO can be summarized in three hypotheses:

(1) ISSO is strongly related to technological changes and therefore emerges most prominently in the high-tech sectors of the economy;

(2) (The effects of) JSSO can be mitigated by stressing generic skills and 'core qualifications' in initial education and by providing sufficient training and learning possibilities after entering the labor force;

(3) ISSO has strong negative consequences for the productivity and emplloyability of those who are affected by it.

Despite these strongly held views among policy makers (and researchers) on the causes and consequences of JSSO, the empirical evidence supporting these hypotheses is scarce and mostly indirect (De Grip \& Van Loo, 2002). The most important reason is that ISSO is usually not directlly measured. Instead economists have concentrated on either possible causes of JSSO, e.g. ICT investment in the economic sector concerned, or at possible consequences of ISSO such as the wage effects in earnings functions. The last type of research usually focuses on the wage effects of career interruptions or unemployment spells (e.g. Mincer \& Ofek, 1982; Jacobson et al., 1993; Blechinger \& Pfeiffer, 2000). However, in the absence of direct measures of JSSO, it is difficult to conclude that the observed wage effects are in fact due to JSSO rather than other factors not controlled for in the model (such as stereotyping by the employer or productivity-related personal characteristics).

Direct assessment of JSSO would ideally involve intensive (psychological) testing in a job specific domain within a repeated longitudinal design. These kinds of surveys are usually restricted to specific occupations (e.g. medical doctors, see for example Newble et al, 1994), and are not practicable for a large cross-section of the labor force. An attractive alternative is the use of workers" self reports on JSSO. Blechinger and Pfeiffer (2000) provide such a direct measure of workers' self assessment. They use data from the BIBB survey among German former apprentices, where the following question was asked: "How much of the occupational knowledge and skills you acquired during your apprenticeship can you still apply in your current work." Blechinger and Pfeiffer show that workers who use little or none of their skills earn much less than those who still make full use of the skills acquired in their apprenticeship. A problem with this approach is that their instrument does not discriminate between JSSO as such and the extent to which a respondent is working in a job that matches his or her apprenticeship training. Respondents working either voluntarily or involuntarily - in jobs not related to their training will almost certainly report that they apply relatively little of the knowledge and 
skills acquired therein. Furthermore, the literature on assignment and job matching shows profound effects of such mismatches on earnings (Hartog, 2000; Van Smoorenburg \& Van der Velden, 2000). It therefore seems likely that at least a part of the negative wage effect which Blechinger and Pfeiffer attribute to skills obsolescence is in fact due to mismatches between acquired and required education. Although it is quite possible that JSSO may contribute to such mismatches, it is cllearly not the same thing. It is therefore of paramount importance to have a measure of JSSO that is independent of the context within which individual respondents apply their skills. Other examples of direct measurement seem to suffer from the same weakness by relating the subjective assessment of ISSO to the current job (see Van Loo et all, 2001).

In this paper we will present an alternative measurement of JSSO, which is also based on workers" self-assessment, but which avoids the above-mentioned weakmesses. The focus will be on JSSO experienced by higher education graduates. Highly educated workers are an interesting group from the point of view of skills obsolescence, because the depreciation rate of knowledge is commonly thought to be strongly related to the level of education. Neumann and Weis (1995) give evidence that higher educated workers are more strongly affected by depreciation of human capital than lower educated workers. In the paper we will explore the extent to which the prevailing views on JSSO hold true for higher education graduates who have about seven years of labor market experience. Judging from estimates in the literature, this group should already experience a serious depreciation of knowledge and skills. The main questions in this article are:

(1) What is the extent of JSSO among higher education graduates seven years after entering the labor force?

(2) To what extent does JSSO differ between the different fields of study? Are 'field-specific' studies more at risk than 'generic' studies?

(3) To what extent does JSSO differ between the economic sectors where the graduates are working? Is JSSO a specific problem for the technologically adwanced sectors?

(4) To what extent could ISSO have been prevented by better preparation during tertiary education?

(5) Does JSSO affect the graduates' current job performance?

(6) Do graduates compensate for JSSO by increased levels of further training?

(7) Does JSSO affect graduates" wages?

The next section briefly describes the data used in this article. Section 3 deals with the incidence and possible causes of JSSO and focuses on questions 1-4. 
Section 4 will address the consequences of JSSO and focuses explicitly on the last three questions. In the closing section some conclusions are drawn.

\section{DATA}

The data used for the analyses are taken from a 1998 survey of Dutch workers who graduated from tertiary education in the academic year 1990-1991. A representative sample of some 6,000 graduates was approached (approximately 4,000 from higher vocational education (in Dutch: hoger beroepsonderwijs, abbreviated as $\mathrm{HBO}$ ) and approximately 2,000 from university education. The total number of returned questionnaires was 2,723 , which resulted in a response rate of $45 \%$.

In the survey much attention has been given to the acquired education, the subsequent transition to working life, the occupational career, the possession and requirement of work related knowledge and skills, the utilization of skills, the degree to which the skills are outdated, work orientations and job satisfaction and training followed after graduation.

In addition to these data, which were used for the main analyses, we have madle use of other data in order to construct an indicator for the relative fieldspecificity of the courses which our respondents followed. These data comprised two cohorts of the HBO and university graduate surveys conducted annually in the Netherlands about one and a half years following graduation (Allen el al., 2000; Ramaekers \& Huijgen, 2000). We used the 1998 and 1999 cohorts, resulting in a combined data set of over 50,000 cases." In these surveys, which use the same detailed educational classification as the survey described above, working graduates are asked to indicate the extent to which a range of competences are important in the current job. We first derived a measure for the degree of field-specificity of a course, this being defined as the mean of the percentage of graduates who stated that "field-specific theoretical knowledge" was important, and the percentage who stated that 'field-specific methods and techniques' were important. For example, if $80 \%$ of graduates of a given course stated that "field-speeific theoretical knowledge" was important, and $60 \%$ stated that "field-specific methods and techniques" were important, that course obtained an average field-specificity score of $(80+60) / 2=70$. By including both indicators to derive the score, we take into account that there are different ways in which courses can be field-specific. In a similar way, the degree to which a course is characterized by a concentration on generic skills is measured as the mean of the percentages of the items 'teamwork,' 'planning and organizing,' 'leadership," "self-reliance," "adaptability" and "accuracy' which were regarded as important. In order to obtain a single measure of the relative degree of 
field-specificity, we divided the former (the degree of field-specificity) by the latter (the degree to which a course is characterized by a concentration on generic skills). The resulting variable for the different courses is near normal distributed, with mean 1.03, standard deviation 0.18 and a skewness of 0.02 .

\section{THE EMERGENCE AND CAUSES OF JOB SPECIFIC SKILLS OBSOLESCENCE}

Although skills obsolescence is a prominent item on the policy and research agenda (see for example De Grip et al., 2000), it is interesting to note that empirical research on the actual measurement of skills obsolescence has been very scarce (De Grip \& Van LoO, 2002). As outlimed in the introduction, most authors do not use direct measures to assess JSSO. If direct measurements of JSSO are used, they are usually restricted to specific occupations because it relates to a specific domain. An attractive alternative is to use workers' selfassessment. It is important that such an instrument is able to distinguish between JSSO and mismatches between acquired education and job content.

In our survey we developed the following measure to assess the JSSO in a very simple and straightforward way. Respondents were asked to answer the following question:

What percentage of the knowledge and skills that you acginired during (tieriary) education is now out of date?

Compared to the other examples of workers' self-assessment given in the introduction, this question has the advantage that the answers are not blurred by the fact that people may be working in a job for which they are not actually trained. ${ }^{2}$ Figure 1 presents the frequency distribution of the answers to this question.

As can be seen from the graph, the response pattern to this question shows a near normal distribution, with a mean of $30 \%$ of the skills being obsolete and a standard deviation of $21 \%$. There are no strong indications that respondents in general had any real trouble answering this question. The item non-response for this question, $5 \%$, is similar to that for other questions in the survey. If we bear in mind that the respondents graduated from tertiary education 7-8 years before the survey was held, this suggests that the average "hall-life' of competencies acquired during tertiary education may lie somewhere in the range between 10 and 15 years. This is a considerably longer period than that used by IRDAC (1990) or those cited in De Grip and Van Loo (2002). However, over the life cycle of the occupational career, this would imply that tertiary graduates have to "renew" their competencies on a fairly regular basis during 


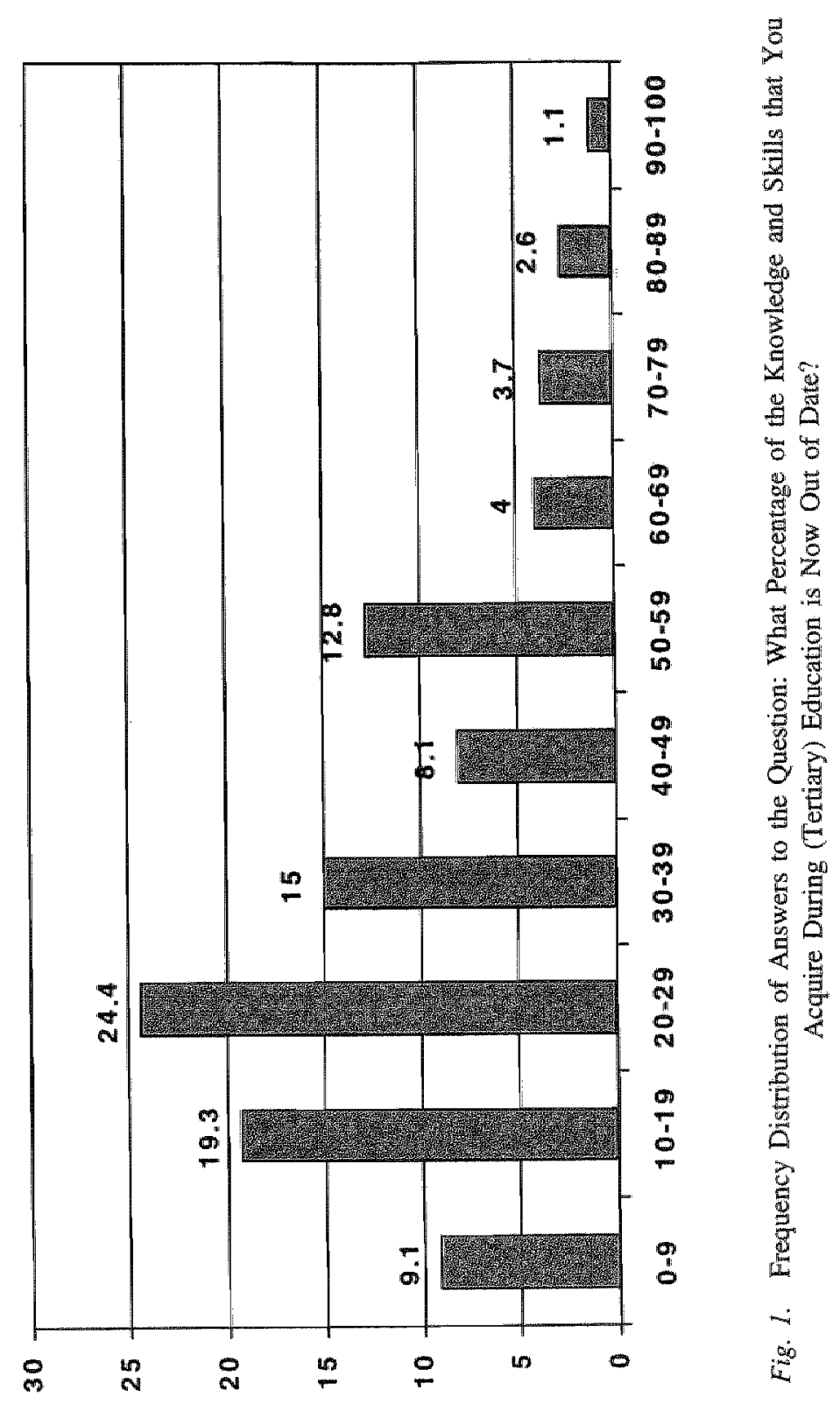


their career. This offers clear justification for the strong emphasis that is often placed on the need for "Iife-long learning."

It is a commonly held view that competencies acquired in courses that focus on a specific (occupational) domain or field of expertise are more likely to become obsolete than those acquired in more generic courses. The reason for this expectation is that the applicability of competencies typical of field-specific courses (for example field-specific knowledge, methods and techniques, knowledge of complex systems, field-specific rules and regulations) tends to be relatively context-specific. Due to for example technological and organizational developments, the context in which skills are applied can change rapidly, making the skills obsolete. By contrast, skills obtairied in more generic courses (for example general knowledge, analytic, problem-solwing, social and attitudinal skills) do not rely heavily for their application on the context in which they are applied. These skills will still be useful, and in fact may be even more useful, in a rapidly changing environment, than in a static situation. The difference between graduates of field-specific and generic courses may be further aggravated if graduates of field-specific courses are more likely to find work in rapidly changing sectors of the labor market, such as information technology. One can therefore expect all graduates working in rapidly changing economic sectors to experience more skills obsolescence than those working in more static sectors. This effect is probably strongest for graduates of field-specific courses.

Table $\|$ shows the mean percentage of self-reported skills obsolescence for the different fields of education.

Table 1. Mean Percentage of Skills Obsolescence, by Field and Type of Tertiary Education.

Type of education:

Weld of sindy:

- Agriculture

- Bductiotion

- Technical

- Economines

- Health

- Social and behavionall

- Arts and humanities

- Law

- Matural sciences

Total

HBO

University

34.6

27.5

34.2

30.7

24.9

26.6

24.11

ก. 站.

ก. ฉ2.

28.8
X

$\mathrm{x}$

28.4

33.9

26.0

31.3

24.5

47.9

30.9

31.7

na.a. = not applicable.

$x=$ too few cases for presentation. 
The table shows that university graduates report a slightly higher rate of JSSO than graduates from higher vocational education (32\% vs. 29\%). The differences between fields of study are more striking. The highest score was not found for technical studies, but rather for university-level law studies: for graduates of these courses almost half of the skills acquired during education were reported as being obsolete. Relatively high scores were also found for the agricultural and technical fields at $\mathrm{HBO}$-level (but not at university level) and for economics and business administration at uniwersity level. Fields of study that show relatively low percentages include health care and arts and humanities (both at HBO and university level), and teacher training and social studies (only for $\mathrm{HBO}$ ).

As was remarked earlier, JSSO could be a result of characteristics of the course of education from which the respondents have graduated. There is a general view that graduates from courses that are highly specific to a particular field of expertise are more subject to JSSO than graduates from generic courses. Although we may intuitively regard some fields of study as more field-specific of more generic, the classification used in Table I is primarily an administrative classification constructed for general descriptive purposes. In order to provide a clearer picture, Table 2 shows the mean relative fieldspecificity scores, as calculated in the manner described in Section 2, per major field of studly.

Table 2. Mean Relative Field-Specificity, by Field and Type of Tertiary Education.

\begin{tabular}{|c|c|c|}
\hline \multirow[b]{2}{*}{ Field of study: } & \multicolumn{2}{|c|}{ Relative field-specificity } \\
\hline & $\mathrm{HBO}$ & University \\
\hline - Agriciulture & 0.89 & $x$ \\
\hline - Education & 0.97 & $\mathrm{x}$ \\
\hline - Technical & 1.04 & 1.08 \\
\hline - Economics & 0.93 & 1.04 \\
\hline Health & 1.17 & 11.22 \\
\hline - Sociall and behaviloral & 0.99 & $\mathbb{1 1 0 0}$ \\
\hline - Arts and humanities & 1.37 & 0.84 \\
\hline - Law & n.a. & 1.12 \\
\hline - Natural sciences & 10. 社. & 1.11 \\
\hline Totall & 1.01 & 1.06 \\
\hline
\end{tabular}

n.a. = not applicable.

$x=$ too few cases for presentation. 
Fields of study with a relatively high degree of field-specificity include health care (at both HBO and university), HBO level arts education and university level law and natural sciences. HBO level agriculture and university level arts and humanities show a relatively low degree of field-specificity.

At first sight there seems to be little in the way of a clear relation between the field-specificity of a field of study and the risk of skills obsolescence. In fact, within $\mathrm{HBO}$ there even appears to be a negative relation. The failure to observe the expected positive relation may be caused by the fact that graduates from different courses work in economic sectors that differ greatly in technological or organizational developments: Table 3 presents the rate of ISSO by the economic sector in which the graduates are presently working. ${ }^{3}$

Table 3 shows that the degree of JSSO indeed differs from sector to sector, but the differences are less pronounced than those between fields of study. Sectors with a relatively low degree of JSSO include "health and welfare," 'culture, recreation and other services' and "education.' Relatively high proportions of JSSO are found in 'construction," 'real estate and commercial services" and 'transport and communication."

As was the case for fields of study, the economic sector classification is an administrative code adopted for general descriptive purposes. This classification may or may not show a strong relation to rapid technological, organizational

Table 3. Mean Percentage of Skills Obsolescence, by Economic Sector.

Economic sector

- Agriculture, forestry and fishing

$\mathrm{x}$

- Mining

- Manufacturing

- Vrillities

- Construction

- Repairs and trade

- Motals, restaurants and catering

- Transport ard communicationa

- Financial institutions

- Heal estate and commercial services

- Holic administration

- Euducation.

- Health and welfare

- Cullure recreation and other services

- Extra-territorial organisations $x$

28.1

$\mathrm{x}$

35.3

31.2

$x$

34.1

32.6

34.5

32.3

26.7

25.7

26.1

$\mathrm{x}$

$x=$ too few cases for presentation. 
or other changes, which we predicted would also strongly influence JSSO. To obtain a more direct measure of this, we asked the respondents whether they agreed to the following statement:

Further training is needed because of new developments in my field of work which could not be foreseen during my course of study (scores ranging from 1 "strongly disagree" to 5 'strongly agree').

Table 4 shows the proportion of graduates per economic sector who agreed with this statement. Relatively low scores are not only found in sectors like "culture, recreation and other services' that also showed allow degree of JSSO, but also in sectors like "construction' and 'transport and communication" where a high degree of ISSO was found.

As was pointed out earlier, ISSO may result from the fact that graduates are employed in sectors that change rapidly. As such, education cannot do much more than just give a proper basis for further competence development. A more serious situation arises when education fails to do so and skills obsolescence arises from shortcomings in the study. Figure 2 tries to provide some insight in these different causes of JSSO. First of all, we divided the total sample into 5 quintiles on the basis of the wariable JSSO. For each of these quintiles, we

Table 4. Percentage Agreeing with Statement: "Further Training is needed because of New Developments in my Field of Work which Could Not be Foreseen During my Course of Study," by Economic Sector.

Economic sector

- Agriculture, forestry and fishing

- Mining

- Manufacturing

- Utilities

- Construction

- Repairs and trade

- Hotels, restauranis and catering

- Transport and communication

- Financial institutions

- Real estate and commercial. services

- Public administration

- Education

- Health and welfare

- Culfure, recreation and other services $\mathrm{x}$ 43.0 60.5 53.9 49.2 66.8 63.6 40.9

- Extra-territorial organisations 

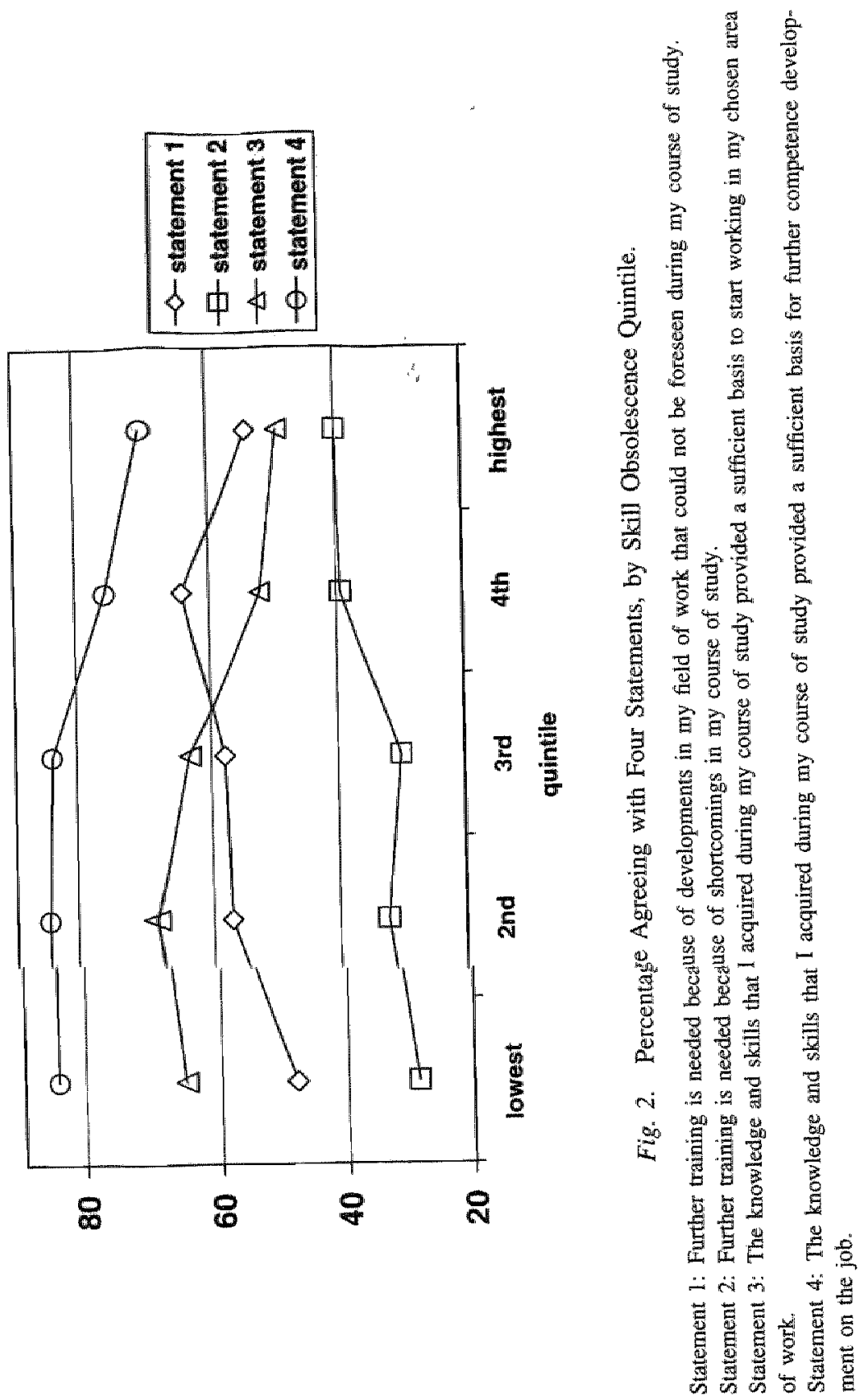
present the percentage of respondents who (strongly) agree with the following statements:

- Further training is needed because of developments in my area of work that could not be foreseen during my course of study (statement 1).

- Further training is needed because of shortcomings in my course of study (statement 2).

- The knowledge and skills that I acquired during my course of study provided a sufficient basis to start working in my chosen area of work (statement 3).

- The knowledge and skills that I acquired during my course of study provided a sufficient basis for further competence development on the job (statement 4).

We would anticipate that graduates who reported a higher degree of JSSO to be more likely to agree that they require further training because of new developments which had occurred in their area of work. This expectation is only partly borne out by the data. As expected, for the first four quintiles there is a clear increase in the percentage of graduates who agreed with statement 1. However, contrary to our expectations, there is a rather abrupt decrease from the fourth to the fifth quintile in the extent to which further training is needed because of new developments. In general. it appears that graduates who report very high levels of JSSO are relatively unlikely to have work characterized by unforeseen new developments. Apart from this anomaly, respondents who regard a large part of the competencies acquired in education as obsolete, tend to agree with the statement that further training is meeded because of developments, which could not be foreseen during the course of study. Such obsolescence could not have been prevented by having a better curriculum.

On the other hand, there is also a clear positive relation between the ISSO and the percentage of graduates indicating that further training is needed because of shortcomings in the study and this relation seems even more straightforward. These shortcomings appear to have an impact right from the start, judging from the clear negative relation between JSSO and the agreement with statement 3 . Apparently courses with a liigh risk of JSSO often do not even provide a sufficient basis to start working in the field of study. Nor do these studies provide a sufficient basis for further competence development as is clear from the negative relation with statement 4 .

Table 5 presents the results of a regression analysis with JSSO as the dependent variable and type of education ( $\mathrm{HBO}$ or university), fields of studly (combined for the different levels of education, reference field economics), the economic sector of work (reference sector manufacturing), the field-specificity of the course of study and the above-mentioned statements as predictors. 
Table 5. Results of Regression Analysis, Dependent Variable Percentage of Skills acquired during Course now Obsolete.

\begin{tabular}{ccc} 
Modell 1 & Model 2 \\
\cline { 2 - 3 } B S.E. & B S.E.
\end{tabular}

Ficld of edication:

- Agriculture

- Education

- Technical

- Economics (reference)

- Health

- Social and behavional

- Arts and humanities

- Law

- Natural sciences

Type of education (university)

Economic sector:

- Manufacturing (reference)

- Repairs and trade

- Transport and cormunuications

- Financial institutions.

- Real estate and commercial serwices

- Public administration

- Education

- Health and welfare

- Culture, recreation and other services

- Other

Field-specificity

Agree with statements:

- New development in area of work

- Shortcomings in course

- Initial skills sufficient

- Initial skills good basis for skill development

Interaction:

- Field-specificity $\times$ Statement 1

Constant

Adjusted R-square

$\begin{array}{rccc}3.58 & 1.95 & 6.22 & 2.96 \\ -1.73 & 1.50 & -6.20 & 2.04 \\ -0.07 & 1.61 & 1.74 & 1.69 \\ - & - & - & - \\ -3.43 & 1.63 & -2.87 & 1.95 \\ -1.03 & 1.44 & -2.41 & 1.63 \\ -6.62 & 1.68 & -6.41 & 2.24 \\ 14.60 & 2.14 & 15.69 & 2.56 \\ -1.57 & 2.33 & 0.58 & 2.54 \\ 1.18 & 1.02 & -0.06 & 1.15\end{array}$

$3.79 \quad 2.53$

$\begin{array}{ll}-3.81 & 3.04\end{array}$

$6.27 \quad 2.60$

$\begin{array}{ll}-6.36 & 2.91\end{array}$

$3.53 \quad 2.33$

$3.66 \quad 2.65$

$5.62 \quad 1.66$

$4.06 \quad 1.88$

2.90

2.03

$5.00 \quad 2.33$

0.75

1.86

0.56

2.27

0.00

1.85

$-0.64$

2.11

0.16

2.21

0.46

2.78

$\mathbf{5 . 8 8} \quad 1.92$

5.76

2.24

$-0.91 \quad 3.11$

$\begin{array}{rr}1.26 & 0.40 \\ 1.57 & 0.42 \\ -2.66 & 0.52 \\ -1.18 & 0.65\end{array}$

$2.51 \quad 2.08$

$27.52 \quad 1.20$

34.48

4.57

Bold figures sigmificant at 0.05 . 
Model 1 includes only level of education, fields of study and economic sector of work as predictors. There is no significant difference between university graduates and HBO graduates in the rate of JSSO. Compared with the reference field of study 'economics," graduates from 'law' show a much higher degree of skills obsolescence, while graduates from 'arts and humanities' experience less skills obsolescence. Comparison of the economic sectors in which the graduates are working shows relatively high levels of skills obsolescence for 'real estate and commercial services' and 'other sectors' compared to the reference sector manufacturing.

Model 2 adds the measure for relative field-specificity of the course followed, plus the agreement to statements 1 to 4 , plus an interaction term between statement $\mathbb{1}$ (new developments) and the field-specificity. Field-specificity is expected to show a positive relation with skills obsolescence. The response to the first two statements, concerning new developments in one"s area of work and shortcomings in the course of study, are also expected to show a positive effect. The last two statements, involving the adequacy of one's course of study as a basis to start working and to develop further skills, are expected to show a negative relation. Finally, as less field-specific skills are thought to provide some protection against the detrimental effects of new developments, the interaction between these two indicators is expected to show a negative effect.

The introduction of these variables improves the model fit considerably (adjusted $\mathrm{R}$ square changes from 0.06 to 0.11 ). The indicator for field-specificity of the course followed does not show any main effect on JSSO. There is a strong. effect of the agreement to statements 1 to 3 , consistent with our earlier findings. Graduates who feel that their skills have become obsolete, also think it necessary to have further training both because of new developments in the sector and because of shortcomings in the course. "They are less likely to agree with the statement that their course provided a sufficient basis to start working in their chosen area of work. On controlling for these effects, no significant effect remains of agreement to the statement referring to the extent to which the course offered a good basis for further skill development. The interaction term between statement 1 and field-specificity has been included in order to test the prediction that the field-specificity of the course would mainly matter when work is characterized by rapid change. No significant negative effect is observed for this interaction term.

\section{CONSEQUENCES OF TOB SPECIFIC SKILLS OBSOLESCENCE}

After investigating the emergence of JSSO and possible causes, we now turn to the effects of JSSO. In this section, we try to assess the extent to which 
skills obsolescence has a detrimental effect on one's ability to perform at work, on the scope provided by one's job to develop new skills, and on one's earnings. We also looked at the degree to which skills obsolescence represents an incentive to invest in further professional training or courses, and at the extent to which such training mitigates any negative productivity effects of skills obsolescence.

To see how JSSO affects the graduates functioning at work we presented them the following statements:

- The knowledge and skills which I acquired in education are sufficient to fulfill my present job adequately (statement 5).

- I could do my job better if I had additional knowledge and skills (statement 6).

- My present job offers me enough possibilities to develop knowledge and skills in the future (statement 7).

Each of these statements could be answered on a 5-point scale ranging from 1 (stronglly disagree) to 5 (strongly agree). For statement 5 we took the percentage of graduates with score 1 or 2 , meaning those who (strongly) disagreed with the statement. This indicator thus represents a skill shortage directly attributable to the course of education followed. By contrast, statement 6 does not refer to the course of study, but simply reflects the current state of knowledge and skills in relation to those required in the job. Differences in the pattern of responses to these two questions can thus be interpreted as differences, in terms of adequacy for the current job, between initial (that is directly after graduation) and current skills. For this statement and also for statement 7 we took the percentage of scores 4 and 5, meaning those who (strongly) agreed with the statements. Figure 3 presents the bivariate results for the five quintiles of JSSO.

The results show a clear relation between JSSO and the degree to which tertiary education provided a good preparation for the present job. Those who report a high degree of ISSO are more often inclined to say that their education did not provide them with the necessary skills to adequately fulfill the job. This rises especially sharply for the highest two quintiles. In the highest quintile, about half of the respondents disagreed with statement 5 , while this proportion is only one third in the lowest quintile. A somewhat similar pattern is observed for statement 6, but this is much less pronounced. Those respondents in the highest two quintiles are somewhat more likely to report a current skill shortage, but the difference with respect to the other groups is not great. Taken together, the results for statements 5 and 6 suggest that although JSSO is clearly related to shortcomings in the course (see also statement 2 in Fig. 2 and Table 5), it is only quite weakly related to current skill shortages. There 

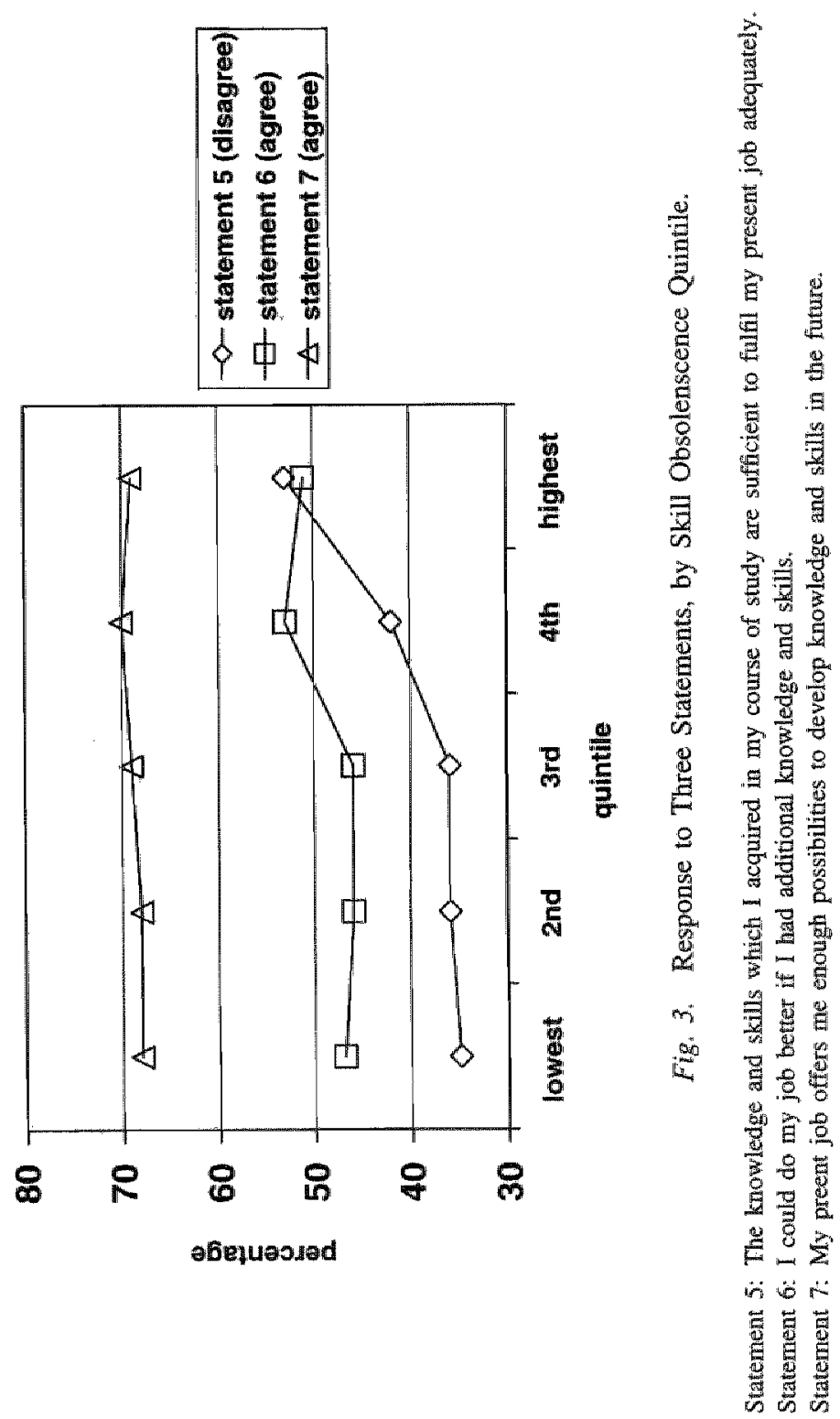
seems to be no relation at all between $\mathrm{ISSO}$ and statement 7 , which suggests that JSSO as such need not pose a serious problem to graduates in terms of the possibilities to further devellop their skills in the future. Regardless of the fact that a part of their acquired skills may be out of date, most graduates think that their present job offers them enough possibilities to further develop their skills.

Figure 4 shows the relation between skill obsolescence and investments in further professional training and other occupationally relevant courses. ${ }^{4}$ In general, ISSO is only likely to be a problem if it results in a skill deficit for a specific worker in a specific situation. Obsolescence of cone skills need not present a problem if workers have invested in replenishing the skill levels through training. It is plausible that the strongest investments in training and schooling will be made more in sectors in which skills obsolescence is more prevalent. However, Fig, 4 shows that contrary to the commonly held view that JSSO would provide an incentive for such investments, there is no clear relation between J JSO on the one hand and the intensity of training efforts on the other hand. Of course this may reflect the fact that training can be followed for a number of reasons, skills absolescence being only one of them. On the other hand, it also reflects the fact that following additional training is not the only way to replenish the skill level. Skills are replenished constantly in many work situations as a result of "leaming by doing."

In the last part of this paper we examine the effects of JSSO on wages. A key question hereby is whether skills obsolescence necessarily has a negative effeet on wages. This relation is not immediately straightforward as we explained before. JSSO can only have a negative effect if it results in a skills deficit. However if workers invest in replenishing their skills, JSSO may not result in llower wages. Moreover, if employers and employees invest more in training in sectors in which skills obsolescence is higher, the need to recoup on these investments may imply that wages are actually higher in these sectors than in sectors experiencing lower levels of obsolescence. Failure to take these effects into sccount could even lead to the spurious conclusion that JSSO increases earnings. In the analysis of the effects of JSSO, we will therefore take into account both investments in training and the characteristics of the economic sector in which graduates are working.

Table 6 shows the results of a regression analysis in which the effect of JSSO on hourly wages is estimated, controlling for field and type of education, education-job match, tenure, age at start of current job (reflecting work experience in addition to thenure), gender, economic sector and investments in professional training and courses. The effects of the control variables are broadly consistent with those found in earlier research. Wages are positively related to tenure and 


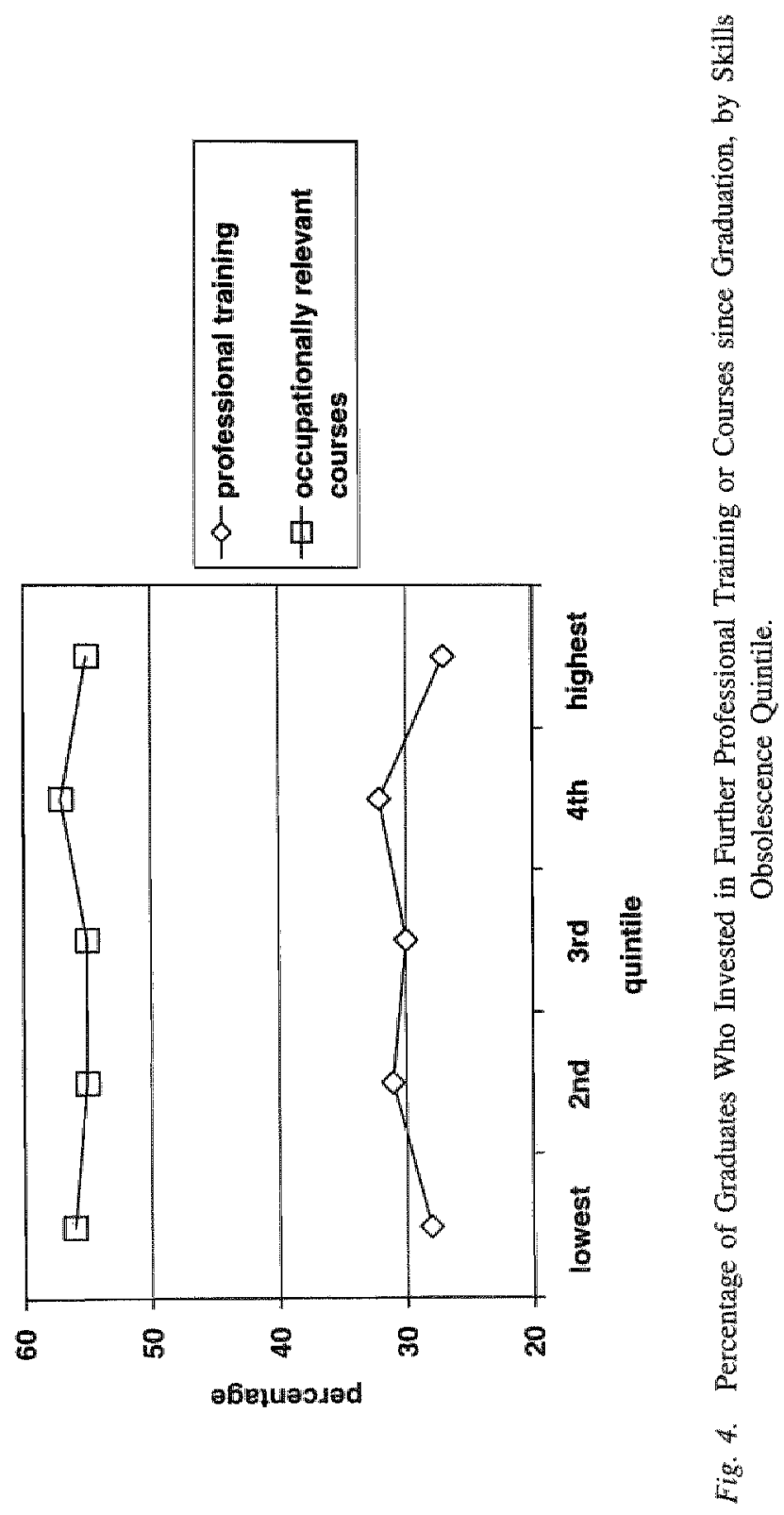


Table 6. Results of Regression Analysis, Dependent Variable Hourly Wage.

\begin{tabular}{llllll}
\hline & \multicolumn{2}{c}{ Model 1 } & & \multicolumn{2}{c}{ Model 2} \\
\cline { 2 - 5 } & B & S.E. & B & S.E. \\
\hline
\end{tabular}

Field of eductation:

- Agriculture

- Education

- Technical

- Economics (reference)

- Health

- Social and behavioral

- Arts and humanities

- Law

- Natural sciences

"Type of education (university)

Education-job match

- At least own lewel of education appropriate

- Own/related bield of education appropriate

Tenure

Age at start of current jolb

Gender (female)

Economic sector

- Manufacturing (reference)

- Repairs and trade

- Transport and comnunications

- Financial institutions

- Real estate and commercial services

- Public administration

- Edurcation

- Health and welfare

- Culture, recreation and other services

- Other

Percentage of skills obsolete

Professional training followed

Courses followed

Constant

Adjusted R-square

$-5.08 \quad 1.03$

$\begin{array}{rl}-1.29 & 0.82\end{array}$

$\begin{array}{ll}-3.03 & 0.86\end{array}$

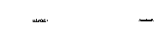

$\begin{array}{ll}-2.05 & 0.88\end{array}$

$\begin{array}{ll}-1,01 & 0.77\end{array}$

$-5.56 \quad 0.9 I$

$0.13 \quad 1.16$

$-6.47 \quad 1.23$

$7.83 \quad 0.56$

$\begin{array}{ll}7.28 & 0.72\end{array}$

$1.24 \quad 0.57$

$\mathbf{0 . 3 2} \quad 0.06$

$0.00 \quad 0.00$

$-2.67 \quad 0.46$

$-0.47$

$-0.02$

1.31

1.37

$\begin{array}{ll}2.59 & 1.21\end{array}$

$0.21 \quad 0.85$

$2.45 \quad 1.04$

$\begin{array}{rl}-4.61 & 1.00\end{array}$

$\begin{array}{ll}-1.92 & 0.98\end{array}$

$-\mathbf{3 . 1 7} \quad 1.16$

$0.91 \quad 1.63$

$\begin{array}{cc}\mathbf{- 5 . 2 2} & 1.04 \\ -0.96 & 0.84 \\ \mathbf{- 2 . 7 6} & 0.88 \\ - & - \\ \mathbf{- 2 . 5 1} & 0.91 \\ \mathbf{- 1 . 7 7} & 0.80 \\ \mathbf{- 5 . 8 5} & 0.93 \\ \mathbf{- 0 . 4 4} & 1.17 \\ \mathbf{- 6 . 5 2} & 1.22 \\ \mathbf{8 . 1 0} & 0.57\end{array}$

$\begin{array}{ll}\mathbf{7 . 2 1} & 0.75\end{array}$

$1.58 \quad 0.59$

$0.33 \quad 0.06$

$0.00 \quad 0.00$

$-2.48 \quad 0.47$

- $\quad-$

$0.40 \quad 1.34$

$0.80 \quad 1.37$

$3.20 \quad 1.23$

$0.87 \quad 0.88$

$3.18 \quad 1.06$

$\begin{array}{ll}-3.96 & 1.02\end{array}$

$\begin{array}{ll}-0.59 & 1.01\end{array}$

$\begin{array}{ll}-1.75 & 1.18\end{array}$

$2.90 \quad 1.68$

$0.01 \quad 0.01$

$0.79 \quad 0.47$

$0.90 \quad 0.44$

$\begin{array}{llll}\mathbf{2 6 . 5 6} & 6.44 & \mathbf{2 3 . 7 7} & 6.64\end{array}$

Bold figures significant at 0.05 .

$0.21 \quad 0.22$


are higher for those working in a job matching their level (and to a lesser extent also their field) of education. University graduates earn considerably more than HBO graduates and women less than men. Economics graduates earn significantly more than graduates in several other fields. Surprisingly, ISSO has absolutely no effect at all on wages, nor has the additional investment in further training. It seems that, whatever the causes of JSSO may be, it does not have any net effect on the earnings of individuals. The absence of an effect of investments in further training does not necessarily mean that investments in human capital subsequent to graduation are unimportant as a remedy for skills obsolescence. First of all, a large part of training of workers occurs informally on the job rather than via formal courses. Secondly, such investments are generally made for different reasons, which may cancel each other out to a large extent. For some employers or employees, skill deficits - which may be due to JSSO or to other causes - may constitute an incentive for investing in further (remedial) training. Such training may show a (spurious) negative relation with wages, due to the (unmeasured) low skill levels of those receiving it. However, employers are also likely to have a strong incentive to invest in the further training of their most capable workers. Such training should be positively related to wages. The different wage effects may well cancel each other out.

\section{CONCLUSIONS}

In this article we focus on the causes and effects of Job Specific Skill Obsolescence (JSSO) among graduates of tertiary education in the Netherlands. The popular view towards ISSO holds that it is strongly related to technological changes and therefore emerges most prominently in the high-tech sectors of the economy. In addition, it is often assumed that (the effects of) JSSO can be mitigated by stressing generic skills and 'core qualifications' in initial education and by providing sufficient training and learning possibilities after entering the labor force. Finally, ISSO is commonly supposed to have strong negative consequences for the productivity and employability of those who are affected by it.

Previous attempts to test these hypotheses have been hampered by the lack of a direct measure for ISSO. Economists have generally made inferences about JSSO, by looking at possible causes of JSSO, such as ICT investment in the economic sector, or by looking at possible consequences of ISSO e.g. the wage effects in earnings functions. In these studies it is difficult if not impossible to disentangle the effects of skills obsolescence and those of other unmeasured factors. The few studies which have used a direct assessment of JSSO 
have either been limited to specific occupations or have confounded skills obsolescence with mismatches between awailable and required education.

In our analyses we have used an alternative measurement of JSSO, based on workers' self-assessment, which awoids the above-mentioned weaknesses. Respondents were asked to answer the following question:

What percentage of the knowledge and silkills that you acquired during (tertiary) education is now oul of datte?

The results we obtained using this measure challenge the conventional wisdom concerning $I S S O$ in several respects. On average, graduates stated that almost a third of the skills they obtained in tertiary education were out of date at the time of the survey. In line with what is generally expected, skills obsolescence appears to be strongly related to rapid changes in the domain within which graduates are working. In addition, there are large differences between courses in the degree of skills obsolescence. This obsolescence appears to be strongly related to shortcomings in the course of tertiary education itself, and to the faillare of the course to offer a good basis for further skill acquisition on the job. Contrary to the expectations howewer, skills obsolescence was found to occur not only in strongly field-specific and technical fields of study, but also in more generic and non-technical fields. In general, following generic or fieldspecific courses has no significant effect on the degree of skills obsolescence in the years following graduation.

Also contrary to the conventional wisdom, there is relatively little evidence that the obsolescence of skills acquired during formall education represents a serious problem in the long term. It is only wealkily related to current skill shortages, and does not have any relation at all to the possibilities which graduates perceived for further skill acquisition in the future. Furthermore, skills obsolescence does not appear to have any effect at all on current wage levels.

Finally, graduates who experienced high levels of JSSO were no more likely to make additional investments in professional training and courses after gradwation than those with lower levels of JSSO. In addition, such investments appear to have no bearing on the (absence of) wage effects of JSSO. These findings do not necessarily mean that investments in human capital subsequent to graduation are unimportant as a remedy for skills obsolescence. First of all, a large part of training of workers occurs informally on the job rather than via formal courses. Secondly, such investments are generally made for different reasons, which may cancel each other out to a large extent. For some employers or employees, skill deficits - which may be due to JSSO or to other causes may constitute an incentive for investing in further (remedial) training. Such training may show a (spurious) negative relation with wages, due to the 
(unmeasured) low skill levels of those receiving it. However, employers are also likely to have a strong incentive to invest in the further training of their most capable workers. Such training should be positively related to wages. The different wage effects may well cancel each other out.

\section{NOTES}

1. There were two main reasons for using this combined dataset rather than deriving the indicators directly from the dataset used for the subsequent analyses. Firstly, the combined dataset is much larger, thereby providing much more reliable estimates. especially for the smaller courses. Secondly, the survey used in the rest of this paper was conducted some $7-8$ years after graduation. The competence measures obtained in this survey are therefore likely to reflect work and learning experiences since graduation as much as or more than the course of tertiary education itself. We expect that the degree to which tertiary studies are specific or generic is quite stable over time, so that the time difference should not pose a serious problem.

2. A slight drawback of this measure is that respondents who work in jobs which don"t closely match their education may experience some difficulty in estimating the correct degree of skills obsolescence, since they are no longer fully aware of the most recent developments within the field of work for which they were trained. This could result in an increased measurement error for these workers. There is however no a priori reason to expect these worker's to systematically overestimate or underestimate the actual level of skills obsolescence.

3. The percentages have not been presented for sectors with less tham 15 respondents.

4. In this paper we thave simply used dummies to represent whether or not respondents have invested in further professional training or other courses respectively. It may be argued that these measures are too rough to capture the investments made. However, the results did not change substantially when we used measures indicating the total duration of professional training or other courses.

\section{REFERENCES}

Allen, I. Ramaekers, G., \& Verbeek, F. (2000). WO-Monitor 1999. Utrecht: VSNU. Cörvers. F., De Grip, A. \& Heijke. H. (2002). Beyond Manpower Plannung: A Labor Market Modet for the Netherlands and its Forecast to 2006. Cheltenham: Edward Elgar (Forthcoming).

De Grip, A., Van Loo, J., \& Sanders, J. (2000). Employability in actiont and industrial employa. bility index. SKOPE Research Papers, No. 5. Oxford and Warwick. Uniwersities.

De Grip, A., \& Van Loo, J. (2002). The Economics of Skills Obsolescence: A Review (this volume) Hartog, J. (2000). Over-education and Earnings: where are we, where should we go? Economics of Education Review, 19.131-147.

IRDAC (1990). Skills Shortages in Europe. IRDAC opinion. Brussels: CEC.

Machin, S., \& Van Reenen, J. (1998). Technology and Changes in Skill Structure: Exidence from Seven OECD Countries. Quarterly Journal of Economics, 113, 1245-1279.

Mincer, J., \& Ofek, H. (1982). Interrupted Work Careers: Depreciation and Restoration of Human Capital. The Jounal of Human Resounces: Education. Manpower and Welfare Policies, $17 / 1$. 
Wational skills Task Forco (1998). Towards a Nathonal Sklts Agenda. First Report of the National Wkills Task Force. Suffolk: Drpartment for Education and Enployment.

Weumann, S., \& Wass. A. (1995). On the Effects of Schooling Vintage on Experience-Earuings Profiles: Therory and Evidence. En ropean Econonic Review, 39,943-955.

Newble, D, Jolly, D. Wakeford, R. (Fis) (1994). The Centifation and Re-certification of Doctors: Isswes whe Assessument of Competence. Cambridge: Cambridge University Press.

Ramakers, $\mathrm{G}$, \& Huijgen, T. (2000). De arbethmanktposine van afgestwdeerden van het hoger beroppsonderwijs. Den Haag: HBO-raad.

Researcheentrum voor Onderwijs en Arbeidsmarkl (1999). De arbeidsmant naar opleiding en berow tot 2004. ROA-R-1999/7. Maastricht: Research Center for Education and the Labor Market.

Wan Loo, J, de Grip A., \& de Steur. M. (2001). skills Obsolescence: Causes and Cures. Intemational Jownal of Mampower, 22, 121-137.

Wan Smoorenburg, M. S. M. \& Van der Veldem, R. K. W. (2000). The Training of School-leavers: Complementarity or Substitution? Escontomics of Education Review, 19, 207-217.

Wolf, E, (2000). "Techurulogy and the Demand for Skills, In: A. de Grip \& $\mathbb{L}$. Borghans (Eds), The Owereducaued Worker? The Economics of Skills Utilization (pp. 27-56). Cheltenham: Edward Elgar. 